\title{
EFFECT OF MULTI-NUTRIENT COMPLEX FERTILIZERS ON GROWTH AND TUBER YIELD OF VERY EARLY POTATO (Solanum tuberosum L.) CULTIVARS
}

\author{
"Wanda Wadas, Tomasz Dziugieł \\ Department of Vegetable Crops, Siedlce University of Natural Sciences and Humanities, B. Prusa 14, 08-110 Siedlce, Poland \\ "e-mail: wwadas@uph.edu.pl
}

Received: 12.10.2012

\begin{abstract}
The aim of the study was to compare the effect of multi-nutrient complex fertilizers (HydroComplex, Nitrophoska Blue Special and Viking 13 from the nitrophoska group, and Polimag $\mathrm{S}$ from the amophoska group) and single-nutrient fertilizers on the growth and tuber yield of very early potato cultivars ('Aster', 'Fresco', 'Gloria'). The field experiment was carried out on podzolic soil in mid-eastern Poland during 2005-2007. The study showed a greater beneficial effect of HydroComplex and Nitrophoska Blue Special on the growth of very early potato cultivars than that of Viking 13 and Polimag S. The application of HydroComplex and Nitrophoska Blue Special resulted in greater above-ground plant biomass and assimilation leaf area compared with single-nutrient fertilizers; the leaf area index (LAI) was higher by 0.28 and 0.32 , respectively. The differences were smaller and not statistically confirmed with the use of Polimag S and Viking 13. When the multi-nutrient complex fertilizers were applied, leaf weight ratio (LWR), leaf area ratio (LAR) and specific leaf area (SLA) were similar to the single-nutrient fertilizers. Of the multi-nutrient complex fertilizers, only Nitrophoska Blue Special resulted in higher tuber yield, on average by $2.40 \mathrm{t}$ $\times$ ha $^{-1}$, compared with the single-nutrient fertilizers. The studied cultivars showed a similar response to applied fertilizers. LAI for 'Gloria' was higher than for 'Aster' and 'Fresco', with smaller LAR found in 'Gloria'. LWR for 'Fresco' was smaller than for 'Aster' and 'Gloria', with higher SLA found in 'Fresco'. The tuber yield of "Aster" (24.04 $\left.\mathrm{t} \times \mathrm{ha}^{-1}\right)$ was higher on average by $3 \mathrm{t} \times$ ha $^{-1}$ than for 'Fresco' and 'Gloria'.
\end{abstract}

Key words: plant height, above-ground biomass, assimilation leaf area, leaf area index (LAI), leaf weight ratio (LAR), leaf area ratio (LAR), specific leaf area (SLA)

\section{INTRODUCTION}

Climate, cultivar and crop management determine the growth and dry matter production of a potato crop (Solanum tuberosum L.). Total biomass production and potato cultivar accumulation depend on the amount of intercepted photosynthetically active radiation (PAR), which is directly proportional to the plant leaf area index (LAI) [1,2]. The growth duration and leaf area determine the amount of solar radiation intercepted by the canopy and influences the extent of photosynthesis, evaporation, transpiration and the final tuber yield $[3,4]$. Many researchers have reported that the relationship between leaf area and biomass accumulation is linear $[5,6]$. The LAI is one of the physiological parameters indicating the performance of crop growth and partitioning of assimilates. The duration of active leaf growth mainly determines potato yield and is a major limiting factor with early-maturing cultivars $[2,7]$. The LAI value depends not only on the cultivar and phase of plant development, but can also be modified by fertilization, irrigation and other factors $[3,6,8,9]$.

The most important factor that affects the rapid establishment of the crop canopy is the availability of plant nutrients in the soil. Potato has a relatively shallow root system and requires significant nutrient inputs to maintain tuber productivity and quality. The response of potato to deficiency of one nutrient may be greatly influenced by the levels of other nutrients [9]. Fertilization is one of the most important agronomical factors affecting plant growth and potato tuber yield. Profitable potato cultures cannot be developed without chemical and/or organic fertilization. The fertilization must assure the high utilization of cultivar production potential under the environmental conditions of cultivation area. In recent years there has been an increase in the use of multi-nutrient complex fertilizers. Multi-nutrient complex fertilizers supply crops with primary (nitrogen, phosphorus, potassium) and secondary 
(calcium, magnesium, sulphur) nutrients and micronutrients (iron, zinc, manganese, copper, boron, molybdenum) and have the advantage of having each nutrient in each granule. The right proportion of nutrients is a prerequisite for satisfactory plant growth. Efficient application of the proper type and amount of fertilizer is an important part of achieving profitable yield [10]. There is a lack of research on the effect of using multi-nutrient complex fertilizers in growing early potato cultivars. The use of multi-nutrient complex fertilizers in the cultivation of several potato cultivars, belonging to different maturity groups, has caused the greatest increase in tuber yield of a very early-maturing cultivar [11]. The aim of this study was to compare the effect of selected multi-nutrient complex fertilizers and single-nutrient fertilizers on the growth and tuber yield of very early potato cultivars.

\section{MATERIALS AND METHODS}

\section{Site and season}

The study was carried out at the Agricultural Experimental Station of Siedlce University of Natural Sciences and Humanities $\left(52^{\circ} 09^{\prime} \mathrm{N}, 22^{\circ} 16^{\prime} \mathrm{E}\right)$, during the three growing seasons from 2005-2007, on podzolic soil with a very high content of available phosphorus, a medium to very high content of potassium, a medium content of magnesium and manganese, a low content of boron, a low to medium content of copper and iron as well as a medium to high content of zinc (Table 1). The organic carbon content in the soil ranged from 5.5 to $6.1 \mathrm{~g}^{\circ} \mathrm{kg}^{-1}$ of soil, $\mathrm{pH}$ in $1 \mathrm{~mol} \times \mathrm{dm}^{-3} \mathrm{KCl}$ from 5.0 to 6.8. In each year of the study, spring triticale was grown as a potato forecrop. Farmyard manure was applied in autumn, at a rate of $30 \mathrm{t} \times \mathrm{ha}^{-1}$.

Table 1

Selected soil chemical properties at the experimental site

\begin{tabular}{ccccccccccc}
\hline \multirow{2}{*}{ Years } & \multirow{2}{*}{$\mathrm{pH}$ in KCl } & $\mathrm{C}_{\text {org }}\left(\mathrm{g} \times \mathrm{kg}^{-1}\right)$ & \multicolumn{8}{c}{ Available forms $\left(\mathrm{mg} \times \mathrm{kg}^{-1}\right)$} \\
\cline { 4 - 10 } & & & $\mathrm{P}$ & $\mathrm{K}$ & $\mathrm{Mg}$ & $\mathrm{B}$ & $\mathrm{Mn}$ & $\mathrm{Cu}$ & $\mathrm{Zn}$ & $\mathrm{Fe}$ \\
\hline 2005 & 6.85 & 8.24 & 141 & 216 & 33 & 0.75 & 119.0 & 2.7 & 7.0 & 1056 \\
2006 & 5.00 & 6.09 & 89 & 100 & 39 & 0.23 & 77.3 & 2.0 & 6.4 & 690 \\
2007 & 5.00 & 5.51 & 102 & 75 & 34 & 0.18 & 79.8 & 2.3 & 6.1 & 670 \\
\hline
\end{tabular}

\section{Plant material and experimental design}

The field experiment was established as a split-plot design with three replications. The experimental factors were as follows: I - type of fertilizer: control treatment without fertilizer, single-nutrient fertilizers (ammonium nitrate 34\%, superphosphate 19\%, potassium sulphate 50\%), HydroComplex (NPKMgS 12-11-18-2,6-8 + B, Mn, Zn, Fe; produced by Yara International ASA, Norway), Nitrophoska Blue Special (NPKMgS 12-12-17-2-6 + B, Zn; produced by COMPO GmbH\&Co.KG, Germany), Viking 13 (NPKMgCaS 13-13-21-1,2-4-1,4; produced by Yara International ASA, Norway) representing the nitrophoska group, and Polimag S (NPKMgS 10-8-15-5-14 + B, Cu, $\mathrm{Mn}, \mathrm{Zn}$; produced by Zakłady Chemiczne POLICE S.A., Poland) from the amophoska group; II - cultivar: 'Aster' (Poland), 'Fresco' (The Netherlands) and 'Gloria' (Germany). The multi-nutrient complex fertilizers and single-nutrient fertilizers were applied in spring, in the amounts equivalent to the recommended rates for the cultivars studied $\left(100 \mathrm{~kg} \mathrm{~N} \times \mathrm{ha}^{-1}\right)$. The remaining elements in the single-nutrient fertilizers were applied at rates which guarantee an appropriate N:P:K proportion for edible potatoes, i.e. 1:1:1.5. In the successive years, 4-week pre-sprouted seed potatoes were planted on 15, 20 and 18 April, with row spacing of
$0.30 \mathrm{~m}$ and $0.625 \mathrm{~m}$ between rows. The plots were four rows wide and $6 \mathrm{~m}$ long. The plot area was $15 \mathrm{~m}^{2}$. The average length of sprouts at the time of planting was $15-20 \mathrm{~mm}$. Potato cultivation was carried out according to the rules of good agronomical practice. After 60 days from planting, the height of plants, mass of leaves, mass of stems, assimilation leaf area and leaf area index (LAI) were determined. The measurements were made on four successive plants per plot. The assimilation leaf area was measured by the weight method [12]. The leaf weight ratio (LWR), leaf area ratio (LAR) and specific leaf area (SLA) were also determined. LWR and LAR were defined as the ratio of mass of leaves/ mass of the whole plant and a ratio of assimilation leaf area/mass of the whole plant, respectively. SLA was defined as a ratio of assimilation leaf area/mass of leaves [13]. Potatoes were harvested at the tuber physiological maturity stage, on 25 and 31 July and 8 August, respectively. The total tuber yield was determined. The results of the study were analysed statistically by means of analysis of variance for split-plot design. The significance of differences was verified using Tukey's test at $\mathrm{P}=0.05$.

Over the three-year period of the study, the most favourable thermal and moisture conditions for the cultivation of very early potato cultivars were in the growing season of 2007 (Table 2). The mean monthly 
temperatures were above the long-term average. Total precipitation in May and July was slightly above the long-term average. In 2005 the growth and development of plants was hindered by a low air temperature after planting potatoes and drought from mid-June to the end of the growing period. In 2006 it was hampered by mild drought throughout the potato growing period. In 2005 total precipitation from mid-June to the third week of July amounted only $10.5 \mathrm{~mm}$. In 2006 total precipitation in June and July was almost 3 times lower and over 3.5 times lower, respectively, than the long-term average.

Table 2

Mean air temperature $\left({ }^{\circ} \mathrm{C}\right)$ and precipitation total $(\mathrm{mm})$ in the potato growing period

\begin{tabular}{|c|c|c|c|c|c|c|c|c|c|c|c|c|c|c|c|c|c|}
\hline \multirow{3}{*}{ Months } & \multicolumn{10}{|c|}{ Temperature } & \multicolumn{4}{|c|}{ Precipitation } & \multicolumn{3}{|c|}{$\begin{array}{c}\text { Selyaninov's } \\
\text { hydrothermal } \\
\text { coefficient }\end{array}$} \\
\hline & \multicolumn{3}{|c|}{2005} & \multicolumn{3}{|c|}{2006} & \multicolumn{3}{|c|}{2007} & \multirow{2}{*}{$\begin{array}{l}\text { many } \\
\text { year }\end{array}$} & \multirow{2}{*}{2005} & \multirow{2}{*}{2006} & \multirow{2}{*}{2007} & \multirow{2}{*}{$\begin{array}{c}\text { many } \\
\text { year }\end{array}$} & \multirow{2}{*}{2005} & \multirow{2}{*}{2006} & \multirow{2}{*}{2007} \\
\hline & $\mathrm{t}_{\min }$ & $\mathrm{t}_{\max }$ & $\mathrm{t}_{\text {mean }}$ & $\mathrm{t}_{\min }$ & $\mathrm{t}_{\max }$ & $\mathrm{t}_{\text {mean }}$ & $\mathrm{t}_{\min }$ & $\mathrm{t}_{\max }$ & $\mathrm{t}_{\text {mean }}$ & & & & & & & & \\
\hline April & 6.0 & 11.2 & 8.6 & 5.4 & 12.6 & 8.4 & 5.5 & 10.6 & 8.6 & 8.1 & 12.3 & 29.8 & 21.2 & 49.6 & 0.5 & 1.2 & 0.8 \\
\hline May & 9.8 & 18.3 & 13.0 & 11.6 & 15.0 & 13.6 & 8.8 & 20.7 & 14.4 & 11.2 & 64.7 & 39.6 & 59.1 & 48.2 & 1.6 & 0.9 & 1.3 \\
\hline June & 12.3 & 18.2 & 15.9 & 11.0 & 22.2 & 17.2 & 15.5 & 20.5 & 18.2 & 16.7 & 44.1 & 24.0 & 59.0 & 67.7 & 0.9 & 0.5 & 1.1 \\
\hline July & 18.7 & 21.2 & 20.2 & 20.3 & 23.8 & 22.3 & 16.3 & 21.8 & 18.9 & 19.3 & 86.5 & 16.2 & 70.2 & 59.6 & 1.4 & 0.2 & 1.2 \\
\hline
\end{tabular}

Hydrothermal coefficient value: up to 0.5 strong drought; 0.51-0.69 drought; 0.70-0.99 mild drought; $\geq 1$ no drought

\section{RESULTS}

\section{Plant height and above-ground plant biomass}

The type of fertilizer (single-nutrient or multi-nutrient complex fertilizer) had a slight effect on the height of plants (Fig. 1). The plants were higher on average by $0.044 \mathrm{~m}$ with the use of single-nutrient fertilizer. With the application of multi-nutrient complex fertilizers, they were higher by 0.028 to $0.053 \mathrm{~m}$ in comparison with the control treatment without mineral fertilization. The differences in plant height between the types of fertilizers were not statistically confirmed.

The fertilizers applied in the experiment exerted a greater influence on the growth of 'Aster' than "Fresco' and 'Gloria' (Fig. 1). The differences in plant height between the cultivars studied were not statistically confirmed (Table 3).

The type of fertilizer had a significant effect on above-ground plant biomass (Fig. 2, Fig. 3). The plants produced greater above-ground plant biomass with the application of multi-nutrient complex fertilizers. The above-ground plant biomass was on average higher by $0.028 \mathrm{~kg}(24.8 \%)$ with the use of single-nutrient fertilizers and by $0.033 \mathrm{~kg}(29.2 \%)$ to $0.055 \mathrm{~kg}(48.7 \%)$ with the application of multi-nutrient complex fertilizers compared with the cultivation without mineral fertilization. The plants had the highest above-ground biomass with the use of HydroComplex and Nitrophoska Blue Special (from the nitrophoska group with microelements). During the 3-year experimental period, the application of HydroComplex resulted in an incre- ase of leaf mass on average by $0.022 \mathrm{~kg}(14.1 \%)$ and the mass of stems by $0.027 \mathrm{~kg}(19.1 \%)$ in comparison with the single-nutrient fertilizer, whereas these differences were respectively $0.017 \mathrm{~kg}(11.4 \%)$ and 0.020 $\mathrm{kg}(14.2 \%)$ with the use of Nitrophoska Blue Special. The differences were smaller and not statistically confirmed with the use of the other multi-nutrient complex fertilizers.

The effect of fertilizers on the increase in above-ground plant biomass depended to a higher degree on weather conditions during the potato growing season and on the content of plant nutrients in the soil. The highest increase in above-ground parts resulting from the application of HydroComplex and Nitrophoska Blue Special was reported in the warm and moderately wet growing season in 2007 (Fig. 2, 3). In that year, the leaf mass was higher on average by $0.038 \mathrm{~kg}$ $(19.6 \%)$ and the stem mass was higher by $0.045 \mathrm{~kg}$ (21.2\%) with the use of HydroComplex compared to the single-nutrient fertilizers, whereas with the application of Nitrophoska Blue Special the differences were $0.044 \mathrm{~kg}(22.7 \%)$ and $0.033 \mathrm{~kg}(15.6 \%)$, respectively. The difference between HydroComplex and Nitrophoska Blue Special was not significant. The use of Viking 13 (from the nitrophoska group without microelements) and Polimag S (from the amophoska group with microelements) resulted in a significant increase in above-ground plant biomass in comparison with single-nutrient fertilizers only in 2005 in the soil rich in available nutrients.

The type of fertilizer and cultivar interaction effect on above-ground plant biomass was not statistically 
confirmed (Table 4). The rate of plant growth was cultivar-dependent. Regardless of the type of fertilizer applied, above-ground plant biomass was higher for 'Gloria' than for 'Aster' and 'Fresco' with a compara- ble height of plants (Table 3). The difference between 'Aster' and 'Fresco' was not significant. The largest differences between cultivars were observed in the very warm and moderately wet growing season in 2007.

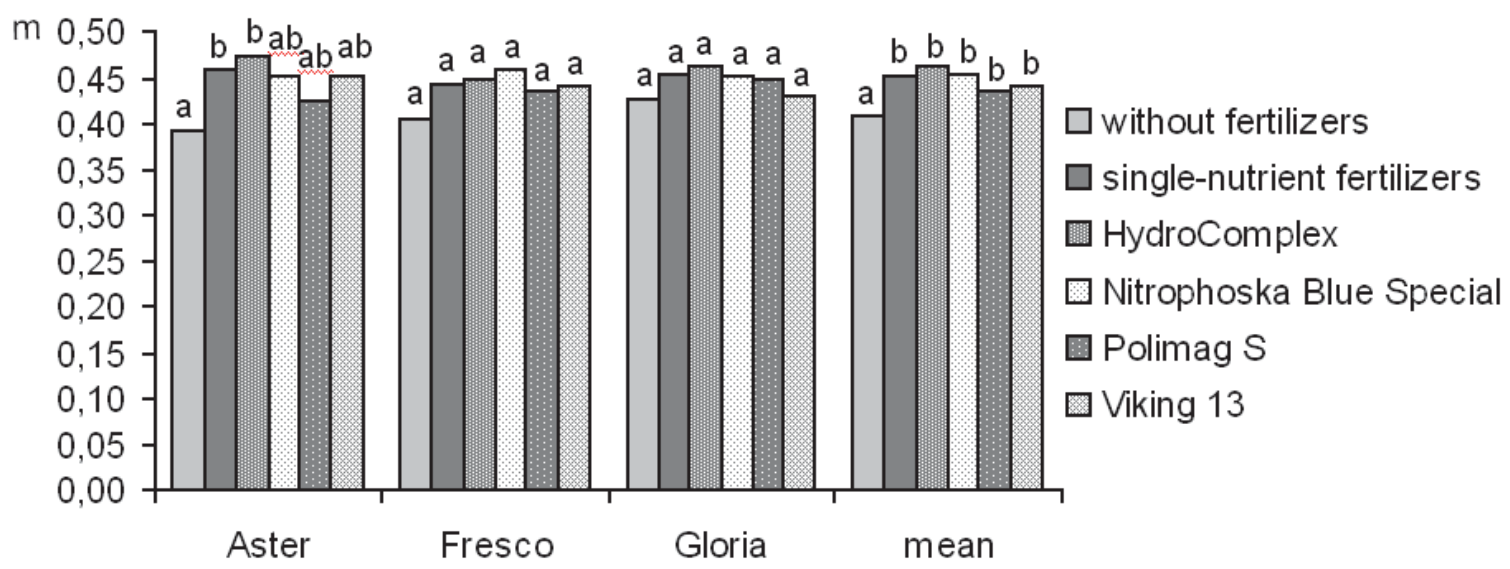

Fig. 1. Plant height in relation to the type of fertilizer and cultivar $(\mathrm{m})$ - means followed by the same letter do not differ significantly at $\mathrm{P}=0.05$

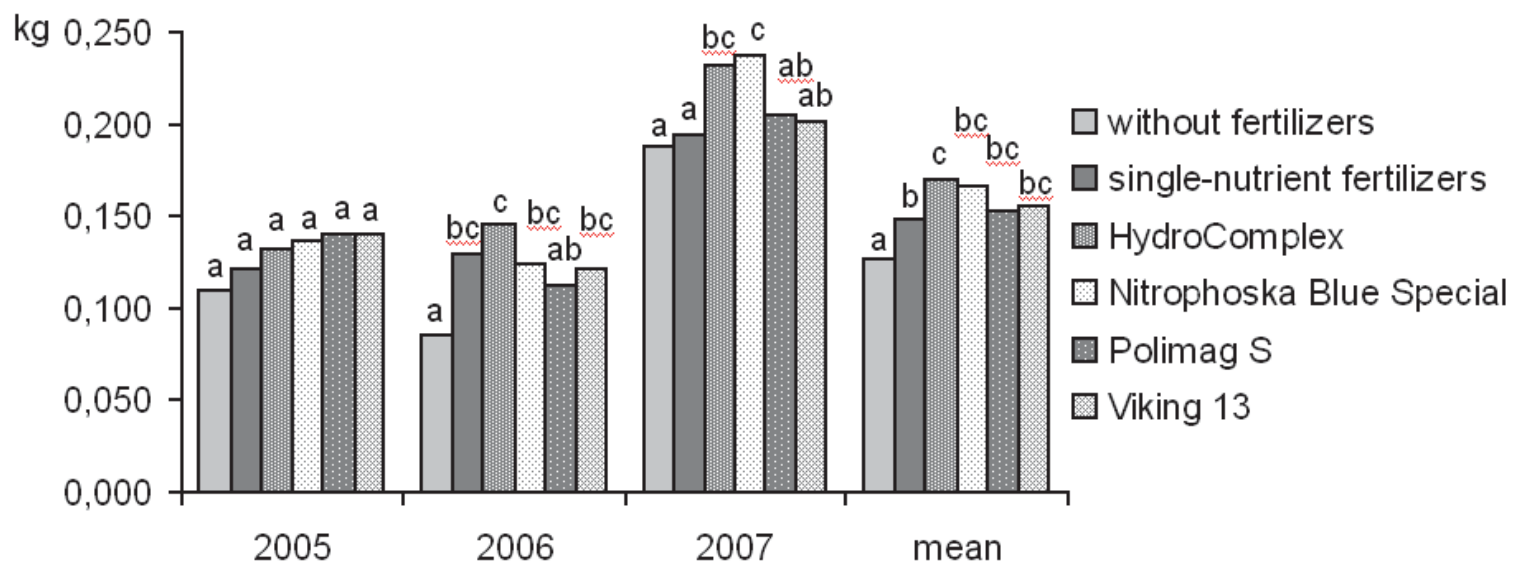

Fig. 2. Mass of leaves per plant in relation to the type of fertilizer and potato growing season $(\mathrm{kg})$ - means followed by the same letter do not differ significantly at $\mathrm{P}=0.05$

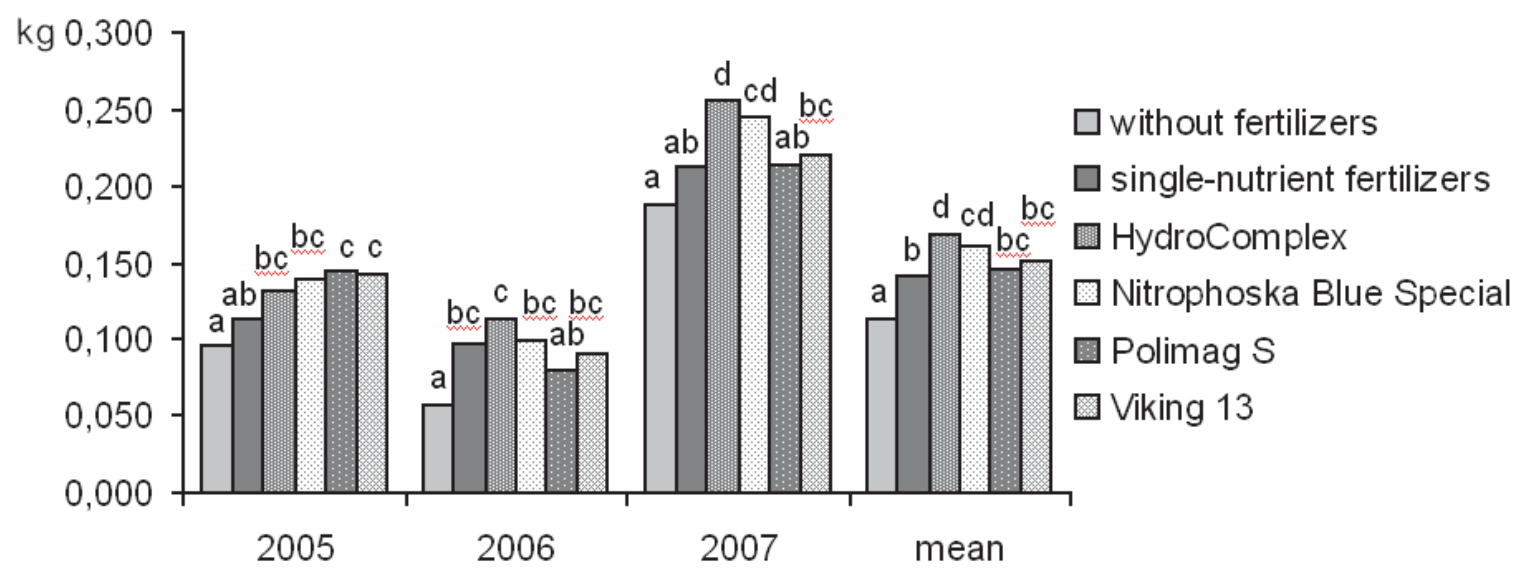

Fig. 3. Mass of stems per plant in relation to the type of fertilizer and potato growing season $(\mathrm{kg})$ - means followed by the same letter do not differ significantly at $\mathrm{P}=0.05$ 
Table 3

Plant height $(\mathrm{m})$ and above-ground biomass $(\mathrm{kg})$ in relation to the cultivar and potato growing season

\begin{tabular}{|c|c|c|c|c|c|c|c|c|c|c|c|c|}
\hline \multirow{2}{*}{ Cultivar } & \multicolumn{4}{|c|}{ Plant height } & \multicolumn{4}{|c|}{ Mass of leaves per plant } & \multicolumn{4}{|c|}{ Mass of stems per plant } \\
\hline & 2005 & 2006 & 2007 & mean & 2005 & 2006 & 2007 & mean & 2005 & 2006 & 2007 & mean \\
\hline Aster & 0.458 & 0.309 & 0.559 & 0.442 & 0.139 & 0.112 & 0.190 & 0.147 & 0.131 & 0.081 & 0.204 & 0.139 \\
\hline Fresco & 0.427 & 0.349 & 0.540 & 0.439 & 0.110 & 0.121 & 0.177 & 0.136 & 0.109 & 0.103 & 0.178 & 0.130 \\
\hline Gloria & 0.424 & 0.331 & 0.582 & 0.446 & 0.141 & 0.127 & 0.263 & 0.177 & 0.144 & 0.085 & 0.287 & 0.172 \\
\hline Mean & 0.436 & 0.329 & 0.560 & 0.442 & 0.130 & 0.120 & 0.210 & 0.153 & 0.128 & 0.090 & 0.223 & 0.147 \\
\hline \multicolumn{13}{|l|}{$\operatorname{LSD}(\mathrm{P}=0.05)$ for: } \\
\hline years & \multicolumn{4}{|c|}{0.016} & \multicolumn{4}{|c|}{0.011} & \multicolumn{4}{|c|}{0.009} \\
\hline cultivar & \multicolumn{4}{|c|}{ ns } & \multicolumn{4}{|c|}{0.015} & \multicolumn{4}{|c|}{0.014} \\
\hline years $\times$ cultivar & \multicolumn{4}{|c|}{0.035} & \multicolumn{4}{|c|}{0.026} & \multicolumn{4}{|c|}{0.024} \\
\hline
\end{tabular}

ns - not significant

Table 4

Leaf area index $\left(\mathrm{LAI}, \mathrm{m}^{2} \times \mathrm{m}^{-2}\right)$ in relation to the type of fertilizer and potato growing season

\begin{tabular}{lcccc}
\hline \multirow{2}{*}{\multicolumn{1}{c}{ Type of fertilizer }} & \multicolumn{3}{c}{ Years } & Mean \\
\cline { 2 - 3 } & 2005 & 2006 & 2007 & 2.01 \\
\hline Without fertilizers & 1.64 & 1.33 & 3.04 & 2.41 \\
Single-nutrient fertilizers & 1.89 & 2.01 & 3.33 & 2.69 \\
HydroComplex & 1.86 & 2.31 & 3.90 & 2.73 \\
Nitrophoska Blue Special & 1.92 & 2.06 & 4.20 & 2.26 \\
Polimag S & 1.98 & 1.76 & 3.03 & 2.37 \\
Viking 13 & 1.95 & 1.88 & 3.28 & \\
\hline LSD (P=0.05) for: years -0.16 ; type of fertilizer -0.28 ; years $\times$ type of fertilizer -0.49 &
\end{tabular}

LSD $(\mathrm{P}=0.05)$ for: years -0.16 ; type of fertilizer -0.28 ; years $\times$ type of fertilizer -0.49

\section{Assimilation leaf area and leaf area index (LAI)}

The fertilizers used in the experiment had a significant effect on the assimilation leaf area (Fig. 4). The assimilation leaf area was on average higher by $0.0756 \mathrm{~m}^{2}(20.1 \%)$ with the use of single-nutrient fertilizers and by $0.0473 \mathrm{~m}^{2}(12.5 \%)$ to $0.1353 \mathrm{~m}^{2}(36.0 \%)$ with the application of multi-nutrient complex fertilizers compared with the cultivation without mineral fertilization. The value of the leaf area index (LAI) was higher respectively by $0.40 \mathrm{~m}^{2} \times \mathrm{m}^{-2}(19.9 \%)$ and by 0.25 to $0.72 \mathrm{~m}^{2} \times \mathrm{m}^{-2}(35.8 \%)$ (Tab. 4). The highest assimilation leaf area and LAI were reported with the use of Nitrophoska Blue Special and HydroComplex (from the nitrophoska group with microelements). With the application of these fertilizers, the assimilation leaf area was higher by $0.0597 \mathrm{~m}^{2}(13.2 \%)$ and $0.0559 \mathrm{~m}^{2}(12.4 \%)$, respectively, in comparison with single-nutrient fertilizers. During the 3year experimental period, the LAI value amounted to $2.73 \mathrm{~m}^{2} \times \mathrm{m}^{-2}$ and $2.69 \mathrm{~m}^{2} \times \mathrm{m}^{-2}$, respectively, and was higher by $0.32 \mathrm{~m}^{2}$ $\times \mathrm{m}^{-2}(13.3 \%)$ and $0.28 \mathrm{~m}^{2} \times \mathrm{m}^{-2}(11.6 \%)$ than with the use of single-nutrient fertilizers. The highest differences were observed in the warm and moderately wet growing season in 2007. In that year, the assimilation leaf area was on average higher by $0.1637 \mathrm{~m}^{2}(26.2 \%)$ with the application of Nitrophoska Blue Special and by $0.1176 \mathrm{~m}^{2}(18.8 \%)$ with the use of HydroComplex compared with single-nutrient fertilizers. The LAI value for HydroComplex was $3.90 \mathrm{~m}^{2} \times \mathrm{m}^{-2}$ on average and for Nitrophoska Blue Special it was $4.2 \mathrm{~m}^{2} \times \mathrm{m}^{-2}$. With the use of Viking 13 (from the nitrophoska group without microelements) and Polimag S (from the amophoska group with microelements), the assimilation leaf area and LAI were similar to the application of single-nutrient fertilizers.

The type of fertilizer and cultivar interaction effect on assimilation leaf area was not statistically confirmed. Regardless of the type of fertilizer applied, 'Gloria' had a higher assimilation leaf area than 'Aster' and 'Fresco' (Tab. 5). The LAI for 'Gloria' was on average $2.68 \mathrm{~m}^{2} \times \mathrm{m}^{-2}$, whereas for the 'Aster' it was smaller on average by $0.34 \mathrm{~m}^{2} \times \mathrm{m}^{-2}(12.7 \%)$ and for 'Fresco' - by $0.47 \mathrm{~m}^{2} \times \mathrm{m}^{-2}(17.5 \%)$. The weather conditions were the factor that caused a significant variation in the LAI value for the studied cultivars. The highest differences between cultivars were reported in the very warm and moderately wet growing season in 2007. In that year, the LAI for 'Aster' was lower on average by $0.92 \mathrm{~m}^{2} \times \mathrm{m}^{-2}(22 \%)$ and for 'Fresco' by $1.23 \mathrm{~m}^{2} \times \mathrm{m}^{-2}(29.4 \%)$ in comparison with 'Gloria'. 


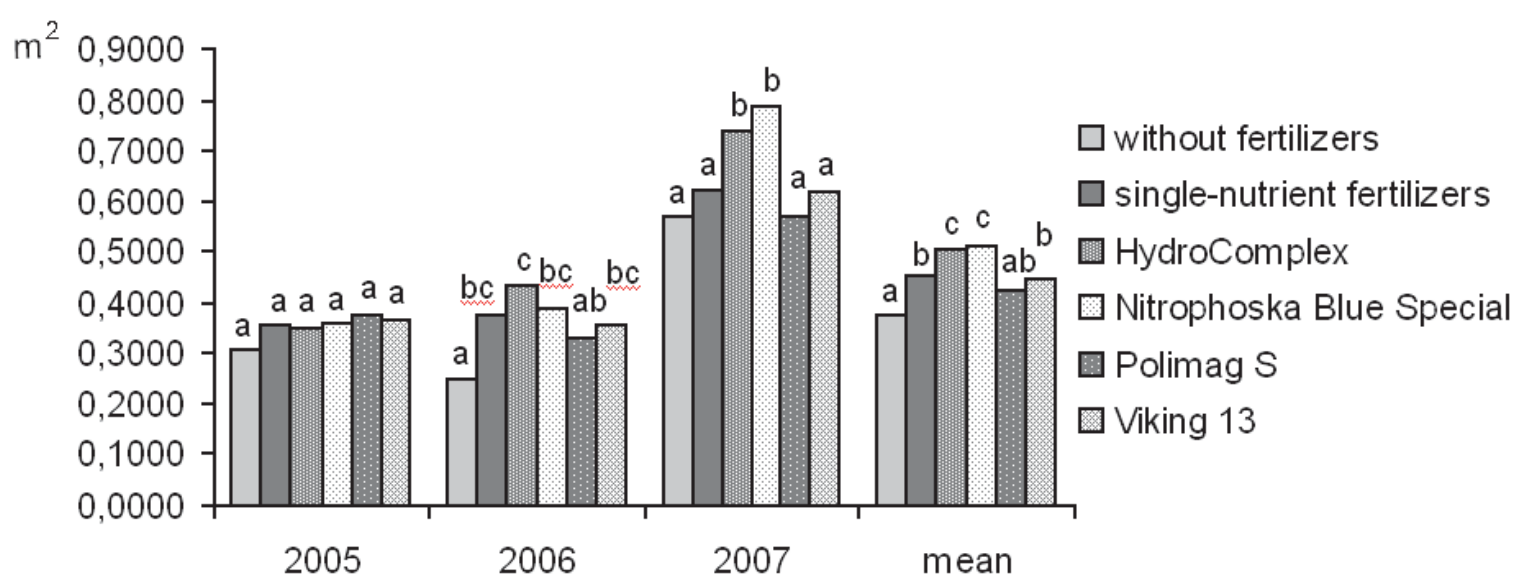

Fig. 4. Assimilation leaf area in relation to the type of fertilizer and potato growing season $\left(\mathrm{m}^{2}\right)-$ means followed by the same letter do not differ significantly at $\mathrm{P}=0.05$

Table 5

Assimilation leaf area $\left(\mathrm{m}^{2}\right)$ and leaf area index $\left(\mathrm{LAI}, \mathrm{m}^{2} \times \mathrm{m}^{-2}\right)$ in relation to the cultivar and potato growing season

\begin{tabular}{|c|c|c|c|c|c|c|c|c|}
\hline \multirow{2}{*}{ Cultivar } & \multicolumn{4}{|c|}{ Assimilation leaf area } & \multicolumn{4}{|c|}{ Leaf area index (LAI) } \\
\hline & 2005 & 2006 & 2007 & mean & 2005 & 2006 & 2007 & mean \\
\hline Aster & 0.3943 & 0.3128 & 0.6115 & 0.4395 & 2.10 & 1.67 & 3.26 & 2.34 \\
\hline Fresco & 0.2894 & 0.3989 & 0.5588 & 0.4157 & 1.54 & 2.13 & 2.95 & 2.21 \\
\hline Gloria & 0.3716 & 0.3529 & 0.7845 & 0.5030 & 1.98 & 1.88 & 4.18 & 2.68 \\
\hline Mean & 0.3518 & 0.3549 & 0.6516 & 0.4528 & 1.88 & 1.89 & 3.46 & 2.41 \\
\hline \multicolumn{9}{|l|}{$\operatorname{LSD}(\mathrm{P}=0.05)$ for: } \\
\hline years & \multicolumn{4}{|c|}{0.0300} & \multicolumn{4}{|c|}{0.16} \\
\hline cultivar & \multicolumn{4}{|c|}{0.0597} & \multicolumn{4}{|c|}{0.31} \\
\hline years $\times$ cultivar & \multicolumn{4}{|c|}{0.1033} & \multicolumn{4}{|c|}{0.54} \\
\hline
\end{tabular}

Leaf weight ratio (LWR), leaf area ratio (LAR), and specific leaf area (SLA)

The fertilizers used in the experiment had a significant effect on the share of assimilation organ in the whole plant mass and plant foliage (Tab. 6). With the application of single-nutrient fertilizers, LWR was smaller on average by $0.025 \mathrm{~kg} \times \mathrm{kg}^{-1}$ and with the use of multi-nutrient complex fertilizers it was lower by 0.030 to $0.037 \mathrm{~kg} \times \mathrm{kg}^{-1}$ in comparison with the cultivation without mineral fertilization. LAR was smaller by $0.080 \mathrm{~m}^{2} \times \mathrm{kg}^{-1}$ and by 0.069 to $0.154 \mathrm{~m}^{2} \times \mathrm{kg}^{-1}$, respectively. The type of fertilizer (single-nutrient or multi-nutrient) did not have a significant effect on the LWR value. LAR was similar with the use of Nitrophoska Blue Special and it was smaller with the application of the other multi-nutrient complex fertilizers compared with single-nutrient fertilizers. Regardless of the type of fertilizer applied, LWR and LAR were highest in 2006 with a mild drought during the potato growing season (Tab. 7).
The type of fertilizer and cultivar interaction effect on LWR and LAR was not statistically confirmed. Regardless of the fertilizer applied, LWR for 'Fresco' was smaller than for 'Aster' and 'Gloria', with the lowest LAR detected in 'Gloria' (Tab. 7).

The specific leaf area (SLA) depended to a higher degree on the cultivar and weather conditions than on fertilization (Tab. 6, Tab. 7). SLA was higher with the application of Nitrophoska Blue Special than with the use of Viking 13. The differences were minor with the application of other fertilizers and they were not statistically confirmed.

The type of fertilizer and cultivar interaction effect on SLA was not statistically confirmed. Regardless of the fertilizer applied, the specific leaf area in 'Fresco' was higher than in 'Aster' and 'Gloria' by $0.111 \mathrm{~m}^{2}$ $\times \mathrm{kg}^{-1}$ and $0.211 \mathrm{~m}^{2} \times \mathrm{kg}^{-1}$, respectively (Tab. 7). The highest differences between cultivars were reported in 2006, i.e. in the year with the lowest rainfall. In that year, SLA for 'Fresco' was higher on average by $0.487 \mathrm{~m}^{2} \times \mathrm{kg}^{-1}$ than in 'Aster' and 'Gloria'. 
Table 6

Leaf weight ratio $\left(\mathrm{LWR}, \mathrm{kg} \times \mathrm{kg}^{-1}\right)$, leaf area ratio $\left(\mathrm{LAR}, \mathrm{m}^{2} \times \mathrm{kg}^{-1}\right)$

and specific leaf area $\left(\mathrm{SLA}, \mathrm{m}^{2} \times \mathrm{kg}^{-1}\right)$

in relation to the type of fertilizer

\begin{tabular}{lccc}
\hline \multicolumn{1}{c}{ Type of fertilizer } & $\begin{array}{c}\text { Leaf weight ratio } \\
\text { (LWR) }\end{array}$ & $\begin{array}{c}\text { Leaf area ratio } \\
\text { (LAR) }\end{array}$ & $\begin{array}{c}\text { Specific leaf area } \\
\text { (SLA) }\end{array}$ \\
\hline Without fertilizers & 0.548 & 1.626 & 2.976 \\
Single-nutrient fertilizers & 0.523 & 1.546 & 2.965 \\
HydroComplex & 0.511 & 1.493 & 2.926 \\
Nitrophoska Blue Special & 0.517 & 1.557 & 2.988 \\
Polimag S & 0.518 & 1.498 & 2.963 \\
Viking 13 & 0.517 & 1.472 & 2.849 \\
LSD (P=0.05) for: & & & 0.096 \\
type of fertilizer & 0.019 & & 0.131 \\
\hline
\end{tabular}

Table 7

Leaf weight ratio $\left(\mathrm{LWR}, \mathrm{kg} \times \mathrm{kg}^{-1}\right)$, leaf area ratio $\left(\mathrm{LAR}, \mathrm{m}^{2} \times \mathrm{kg}^{-1}\right)$

and specific leaf area (SLA, $\mathrm{m}^{2} \times \mathrm{kg}^{-1}$ )

in relation to the cultivar and potato growing season

\begin{tabular}{|c|c|c|c|c|c|c|c|c|c|c|c|c|}
\hline \multirow{2}{*}{ Cultivar } & \multicolumn{4}{|c|}{$\begin{array}{l}\text { Leaf weight ratio } \\
\text { (LWR) }\end{array}$} & \multicolumn{4}{|c|}{$\begin{array}{l}\text { Leaf area ratio } \\
\qquad(\mathrm{LAR})\end{array}$} & \multicolumn{4}{|c|}{$\begin{array}{c}\text { Specific leaf area } \\
\text { (SLA) }\end{array}$} \\
\hline & 2005 & 2006 & 2007 & mean & 2005 & 2006 & 2007 & mean & 2005 & 2006 & 2007 & mean \\
\hline Aster & 0.513 & 0.584 & 0.485 & 0.527 & 1.420 & 1.634 & 1.586 & 1.547 & 2.762 & 2.798 & 3.263 & 2.941 \\
\hline Fresco & 0.504 & 0.544 & 0.495 & 0.514 & 1.336 & 1.794 & 1.592 & 1.574 & 2.650 & 3.283 & 3.221 & 3.052 \\
\hline Gloria & 0.498 & 0.602 & 0.479 & 0.526 & 1.285 & 1.682 & 1.460 & 1.476 & 2.585 & 2.794 & 3.143 & 2.841 \\
\hline Mean & 0.505 & 0.576 & 0.486 & 0.522 & 1.347 & 1.704 & 1.546 & 1.532 & 2.666 & 2.958 & 3.209 & 2.944 \\
\hline \multicolumn{13}{|c|}{$\operatorname{LSD}(\mathrm{P}=0.05)$ for: } \\
\hline years & \multicolumn{4}{|c|}{0.011} & \multicolumn{4}{|c|}{0.055} & \multicolumn{4}{|c|}{0.75} \\
\hline cultivar & \multicolumn{4}{|c|}{0.012} & \multicolumn{4}{|c|}{0.063} & \multicolumn{4}{|c|}{0.084} \\
\hline years $\times$ cultivar & \multicolumn{4}{|c|}{0.022} & \multicolumn{4}{|c|}{0.110} & \multicolumn{4}{|c|}{0.146} \\
\hline
\end{tabular}

\section{Tuber yield}

The productive effects of multi-nutrient complex fertilizers, i.e. HydroComplex, Viking 13 and Polimag S, reflected in an increase in tuber yield in comparison with the cultivation without mineral fertilization were comparable with commonly used single-nutrient fertilizers (Fig. 5). The highest tuber yield was reported with the application of Nitrophoska Blue Special (from the nitrophoska group with the lowest ammonium nitrogen concentration). With the use of this fertilizer, the total tuber yield was higher on average by $2.40 \mathrm{t} \times \mathrm{ha}^{-1}(10.8 \%)$ in comparison with single-nutrient fertilizers. The yield-increasing effect of fertilizers depended on weather conditions. The amount of rainfall during the potato growing season had a greater effect on the outcome of fertilization with
Nitrophoska Blue Special and HydroComplex than with Polimag S and Viking 13. The use of these fertilizers produced better results with sufficient water supply for plants.

The type of fertilizer and cultivar interaction effect on tuber yield was not statistically confirmed. Regardless of the type of fertilizer applied, tuber yield of 'Aster' was higher than of 'Fresco' and 'Gloria' on average by $3.11 \mathrm{t} \times \mathrm{ha}^{-1}(14.8 \%)$ and $2.88 \mathrm{t} \times \mathrm{ha}^{-1}$ (13.6\%), respectively (Tab. 8). The difference between 'Fresco' and 'Gloria' was not significant. The highest differences between cultivars were reported in 2005 with a drought from mid-June to the end of the potato growing period. In that year, tuber yield of 'Aster', which was more tolerant to wet conditions, was almost twice as much as that of 'Fresco' and 'Gloria'. 


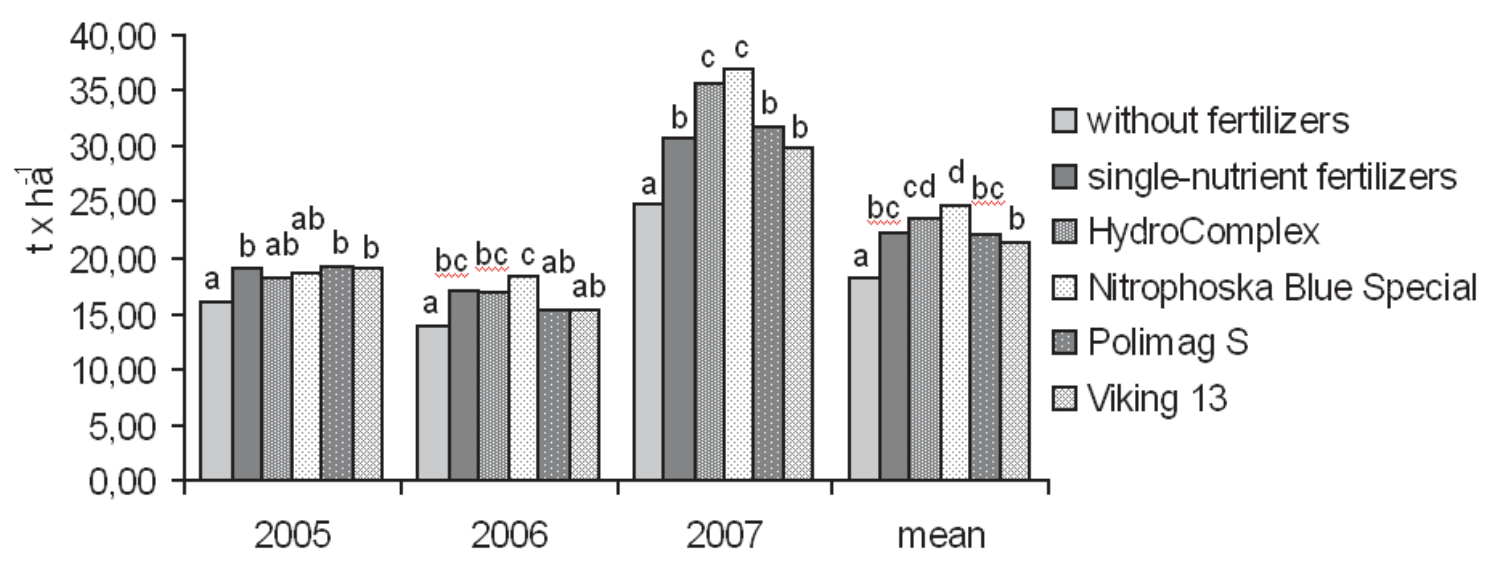

Fig. 5. Tuber yield in relation to the type of fertilizer and potato growing season $\left(\mathrm{t} \times \mathrm{ha}^{-1}\right)-$ means followed by the same letter do not differ significantly at $\mathrm{P}=0.05$

Table 8

Tuber yield $\left(\mathrm{t} \times \mathrm{ha}^{-1}\right)$ in relation to the cultivar and potato growing season

\begin{tabular}{ccccc}
\hline & \multicolumn{3}{c}{ Years } & Mean \\
\cline { 2 - 4 } Cultivar & 2005 & 2006 & 2007 & 24.04 \\
& 26.02 & 14.99 & 31.13 & 20.93 \\
Aster & 13.57 & 17.65 & 31.58 & 21.16 \\
Gresco & 15.30 & 15.86 & 32.32 & 22.04 \\
Mean & 18.29 & 16.16 & 31.68 & \\
\hline
\end{tabular}

$\operatorname{LSD}(\mathrm{P}=0.05)$ for: years -0.98 ; cultivar -1.24 ; years $\times$ cultivar -2.14

\section{DISCUSSION}

Fertilization is one of the most important agronomical factors affecting plant growth and potato tuber yield. Potato has a relatively shallow root system and requires significant nutrient inputs to maintain tuber productivity and quality. Efficient application of the proper type of fertilizer is an important part of achieving profitable tuber yield. Mineral fertilizers have a great impact on nutrient distribution in the soil and their bioavailability for plants [14]. In the present study, the type of fertilizer (single-nutrient or multi-nutrient complex fertilizers) significantly affected the growth of very early potato cultivars. The differences in plant height between the types of fertilizers were not statistically confirmed, but the plants produced greater above-ground plant biomass with the application of multi-nutrient complex fertilizers. Of the multi-nutrient complex fertilizers, HydroComplex and Nitrophoska Blue Special (from the nitrophoska group with microelements) resulted in a higher increase in above-ground plant biomass in comparison with single-nutrient fertilizers.

The duration of active leaf growth mainly determines potato yield and is a major limiting factor with early-maturing cultivars. The leaf area index (LAI) is one of the physiological parameters indicating the performance of crop growth and partitioning of assimilates. The assimilation leaf area and the type of foliage made the architecture of lowland meadows, which largely determines the effectiveness of solar radiation interception. The higher value of LAI affected favourably the growth of tubers during vegetation and even the final tuber yield $[8,15]$. The relationship between the rate of tuber yield and the LAI value is rather diverse, because potatoes respond very sensitively to weather changes during vegetation by falling or new growth of leaves. It often happens that the enlargement of assimilation leaf area does not result in an increase of tuber yield. The LAI value determines light conditions in lowland meadows of crops and the effectiveness of solar radiation interception. The rate of photosynthesis per unit of leaf area decreases with the increase in leaf area. The optimal, and not maximal, assimilation leaf area for a given cultivar ensures maximum tuber yield. With the maximal value of LAI, the growth rate of lowland meadows may be smaller than with optimal LAI due to dying out or low effectiveness of photosynthesis of overshadowed lower leaves. The optimal LAI depends on the density of plants in lowland meadows and on competition (due to density) between plants for light, water and nutrients $[8,13,16]$. The optimum leaf 
area and its duration influenced the extent of photosynthesis, evaporation, transpiration, stolon and tuber initiation, final biomass, and partitioning of dry matter into economic yield [4]. The relative rate of leaf area expansion of potato decreased with thermal time, but was nearly linear up to a LAI of 1.0. The LAI value depends not only on the cultivar and plant growth stage, but can also be modified by fertilization, irrigation and other factors $[3,6,8,9]$. The fertilizers used in the experiment had a significant effect on the increase in above-ground plant biomass and this translated into higher assimilation leaf area in comparison to the cultivation without mineral fertilization. The highest assimilation leaf area and LAI were reported with the use of Nitrophoska Blue Special and HydroComplex (from the nitrophoska group with microelements). The rate of crop plant growth is, to some extent, modified by magnesium and sulphur application which can significantly impact nitrogen uptake and utilization [17,18]. In potato cultivation, some elements, like zinc, boron, sulphur and magnesium, can help in increasing foliage coverage at the initial growth stages and at the later stages [19,20]. B ari et al. [21] observed that the highest plant height and foliage coverage were recorded in the plot where zinc, boron, sulphur and magnesium were applied together, which was also confirmed in the present study. The rate of leaf area expansion showed an interaction between genotype and environment, and varied by year [22], which was confirmed in the present study. Studies have shown a rapid increase in light interception together with an increase in LAI up to 2.5. The light interception rises, though slowly, until LAI reaches $4.0[1,6,23]$. In the present study, the LAI value was higher than $3.0 \mathrm{~m}^{2} \times \mathrm{m}^{-2}$, presumed to be optimal [24], only in 2007, i.e. in a warm and moderately wet year. According to de la $\mathrm{C}$ a s a et al. [25], if potato LAI exceeds 3.0, the intercepted photosynthetically active radiation values change very little, making it very difficult to detect differences due to variations in crop conditions.

The leaf area index (LAI) describes the growth of lowland meadows, whereas the growth of individual plants is characterized with the following indices: leaf weight ratio (LWR), leaf area ratio (LAR), and specific leaf area (SLA). These indices are determined by the genetic features of a cultivar and plant growth stage, but their values can be modified by weather conditions [8,22,24], which was also confirmed in the present study. The fertilizers used in the experiment had a significant effect on the share of assimilation organ in the whole plant mass and plant foliage. The differences in LWR between the types of fertilizers were not statistically confirmed. Of the multi-nutrient complex fertilizers, only Nitrophoska Blue Special resulted in a similar value of LAR as single-nutrient fertilizers. With the use of the other multi-nutrient complex fertilizers, the LAR value was smaller in comparison with single-nutrient fertilizers. The LAR value decreases almost linearly with the growth of plants. This is a result of a decreasing share of assimilation tissues in the whole plant mass. During ontogenesis, the share of assimilating organs in the whole plant decreases more quickly than LAR. A temporary increase in the LAR value can result from a sudden improvement in environmental conditions, e.g. after a drought period or a period of slight frost [13,24]. Z r ů s t and C e pl [15] reported a significant relation between potato tuber yield and LAR, especially for leaf type cultivars. The specific leaf area (SLA) depended to a higher degree on the cultivar and weather conditions than on fertilization. Jenkins and Mahmood [9] showed the relation between potato plant growth, LAI and SLA, and the supply of nitrogen, phosphorus and potassium. The SLA for potato depends on the growth stage and temperature. The early foliar expansion is associated with a strong increase in SLA [22], which was confirmed in the present study.

Of the multi-nutrient fertilizers, only Nitrophoska Blue Special (from the nitrophoska group with the lowest ammonium nitrogen concentration) resulted in a significant increase in tuber yield in comparison with single-nutrient fertilizers. The productive effects of HydroComplex and Viking 13 (from the nitrophoska group), and Polimag $\mathrm{S}$ (from the amophoska group) in very early potato cultivars growing on podzolic soil in mid-eastern Poland were comparable with commonly used single-nutrient fertilizers. The beneficial effects of fertilization with Nitrophoska 12 Special and Nitrophoska 15 Perfect on potato cultivation in semi-coherent soil in north-western Poland were shown in the study carried out by $\mathrm{J}$ a b ł o ń s ki [26]. Potato plants are very sensitive to ammonium toxicity [27]. The yield-increasing effect of the fertilizers applied in the experiment depended on the amount of rainfall during the potato growing season. The use of Nitrophoska Blue Special and HydroComplex produced better results with sufficient water supply for plants.

An appropriate choice of cultivar is very important in early potato production. In the present study, the type of fertilizer and cultivar interaction effect on plant growth and tuber yield was not statistically confirmed. Regardless of the type of fertilizer applied, LAI for 'Gloria' (Germany) was higher than for 'Fresco' (The Netherlands) and 'Aster' (Poland), with the smaller LAR found in 'Gloria'. The difference between 'Fresco' and 'Aster' was not significant. LWR for 'Fresco' was smaller than for 'Aster' and 'Gloria', with a higher value of SLA in 'Fresco'. The highest SLA with the lower LAI indicates that 'Fresco' produced more delicate and thinner leaves. The tuber yield of 'Aster', more 
tolerant to wet conditions, was higher on average by 3 $\mathrm{t}^{\prime} \mathrm{ha}^{-1}$ than for 'Fresco' and 'Gloria'. Over the 3-year experimental period, the tuber yield of 'Aster' was on average $24.04 \mathrm{t} \times \mathrm{ha}^{-1}$.

\section{CONCLUSIONS}

Efficient application of the proper type and amount of fertilizer is an important part of achieving profitable potato tuber yield. The fertilization must assure the high utilization of cultivar production potential under the environmental conditions of cultivation area. The present study showed a greater beneficial effect of multi-nutrient complex fertilizers HydroComplex and Nitrophoska Blue Special (from the nitrophoska group with microelements) on the growth of very early potato cultivars on podzolic soil in mid-eastern Poland than Viking 13 (from the nitrophoska group without microelements) and Polimag S (from the amophoska group). The application of HydroComplex and Nitrophoska Blue Special resulted in greater above-ground plant biomass and higher assimilation leaf area compared with single-nutrient fertilizers; LAI was higher by $0.28 \mathrm{~m}^{2} \times \mathrm{m}^{-2}$ and $0.32 \mathrm{~m}^{2} \times \mathrm{m}^{-2}$, respectively. When the multi-nutrient complex fertilizers were applied, LWR, LAR and SLA were similar to single-nutrient fertilizers. Of the multi-nutrient complex fertilizers, only Nitrophoska Blue Special (from the nitrophoska group with the lowest ammonium nitrogen concentration) resulted in higher tuber yield, on average by 2.40 $\mathrm{t} \times \mathrm{ha}^{-1}$, compared with the single-nutrient fertilizers. The use of this fertilizer produced better results with sufficient water supply for plants. The fertilizers applied in the experiment indicated a similar response of all studied cultivars. The physiological indicators which determine the amount of tuber yield depended on the genetic characters of the cultivar and weather conditions during the potato growing season.

Regardless of the type of fertilizer applied, LAI for 'Gloria' (Germany) was higher than for 'Aster' (Poland) and 'Fresco' (The Netherlands), with smaller LAR found in 'Gloria'. LWR for 'Fresco' was lower than for 'Aster' and 'Gloria', with higher SLA found in 'Fresco'. The tuber yield of 'Aster" $\left(24.04 \mathrm{t} \times \mathrm{ha}^{-1}\right)$ was higher on average by $3 \mathrm{t} \times$ ha $^{-1}$ than for 'Fresco' and 'Gloria'.

\section{Acknowledgements}

Research supported by the Ministry of Science and Higher Education of Poland as part of the statutory activities of the Department of Vegetable Crops, Siedlce University of Natural Sciences and Humanities. Krystyna Struk, Director of Agricultural Experimental Station, is acknowledged for her valuable technical assistance during the field experiments and during harvest operations. The authors would like to acknowledge the Reviewers and Editors for their valuable comments and suggestions for this paper.

\section{Authors' contributions}

The following declarations about authors' contributions to the research have been made: field research: WW; data analyses: TD; writing the manuscript: WW, TD.

\section{REFERENCES}

1. Khurana S.C., McLaren J.S. The influence of leaf area, light interception and season on potato growth. Potato Res. 1982; 25: 329-342. http://dx.doi.org/10.1007/ BF02357290.

2. Geremew E.B., Steyn J.M., Annandale J.G. Evaluation of growth performance and dry matter partitioning of four processing potato (Solanum tuberosum) cultivars. New Zeal J. Crop Hort. 2007; 35(3): 385-393. http:// dx.doi.org/10.1080/01140670709510204.

3. Gordon R., Brown D.M., Dixon M.A. Estimating potato leaf area index for specific cultivars. Potato Res. 1997; 40: 251-266. http://dx.doi.org/10.1007/BF02358007.

4. K u m a r i S. Influence of drip irrigation and mulch on leaf area maximization, water use efficiency and yield of potato (Solanum tuberosum L.). J Agric Sci. (Canada) 2012; 4(1): 71-80. http://dx.doi.org/10.5539/jas.v4n1p71.

5. Jefferies R.A., MacKerron D.K.L. Response of potato genotypes to drought. II. LAI, growth and yield. Ann. Appl. Biol. 1993; 122(1): 105-112. http://dx.doi.org/ 10.1111/j.1744-7348.1993.tb04018.x.

6. Boyd N.S., Gordon R., Martin R.C. Relationship between leaf area index and ground cover in potato under different management conditions. Potato Res. 2002; 45(1): 117-129. http://dx.doi.org/10.1007/BF02736107.

7. Lahlou O., Ouattar S., Ledent J.F. The effect of drought and cultivar on growth parameters, yield and yield components of potato. Agronomie, 2003; 23: 257-268. http://dx.doi.org/10.1051/agro:2002089.

8. Zrůst J., Hlušek J., Jůzl M., Přichystalová $\mathrm{V}$. Vztah nékterých růstových charakteristik a výnosu hliz velmi raných odrůd brambor. /Relationship between certain chosen growth characteristics and yields of very early potato varieties. Rostl Výr. 1999; 45: 503-509. (in Czech)

9. Jenkins P.D., Mahmood S. Dry matter production and partitioning in potato plants subjected to combined deficiencies of nitrogen, phosphorus and potassium. Ann. Appl. Biol. 2003; 143: 215-229. http://dx.doi.org/ 10.1111/j.1744-7348.2003.tb00288.x.

10. Wadas W., Łęczycka T. Efektywność stosowania wieloskładnikowych nawozów kompleksowych w uprawie bardzo wczesnych odmian ziemniaka. / The efficiency of application of complex multi-nutrient fertilizers in cultivation of very early potato cultivar. Biul IHAR 2010; 257/258: 167-173. (in Polish) 
11. Makaraviciute A. Effects of organic and mineral fertilization on the yield and quality of different potato varieties. Agron. Res. 2003; 1(2): 197-209.

12. Roztropowicz S, editor. Metodyka obserwacji, pomiarów i pobierania prób w agrotechnicznych doświadczeniach z ziemniakiem. IHAR, Jadwisin; 1999. (in Polish)

13. Pietkiewicz S. Wskaźnikowa analiza wzrostu roślin. / An indicator-based analysis of plant growth. Wiad. Bot. 1985; 29(1): 29-42. (in Polish)

14. Pisle a D., S a la F. The influence of mineral fertilization on the distribution of nutrients in the soil. Bull UASVM Agriculture, 2012; 69(1): 225-231.

15. Zrů s t J., Č e pl J. Závislost výnosu raných odrůd brambor na nékterých charakteristikách růstu. / Dependence of early potato yield on some growth characteristics. Rostl Výr. 1991;37:925-933. (in Czech)

16. Zarzyńska K. Wartości wskaźników charakteryzujących stan fizjologiczny bulw i rozwój roślin ziemniaka. Cz. V. Rozwój części nadziemnej. / The value of indicators characterizing physiological state of tuber and development of potato plant. Part V. The development of the above-ground part. Biul IHAR 2001;217:151-168. (in Polish)

17. Sharma D.K., Kushwah S.S., Nema P.K., Rathore S.S. Effect of sulphur on yield and quality of potato (Solanum tuberosum L.). Int. J. Agric. Res. 2011; 6(2): 143-148. http://dx.doi.org/10.3923/ijar.2011.143.148.

18. Grendás J., Führs H. The significance of magnesium for crop quality. Plant Soil. 2013; 368: 101-128. http://dx.doi.org/10.1007/s11104-012-1555-2.

19. Westermann D.T. Nutritional requirements of potatoes. Amer. J. Potato Res. 2005; 82(4): 301-307. http://dx.doi. org/10.1007/BF02871960.

20. Kumar V., Vyakarnahal V.S., Basavaraj N., Kulkarin S., Shekhargouda M. Influence of mikronutrients on growth and yield of potato (Solanum tuberosum) cultivars. Indian. J. Agric. Sci. 2008; 78(9): 752-756.

21. Bari M.S., Rabbani M.G., Rahman M.Sq., Islam M.J., Hoque ATMR. Effect of zinc, boron, sulphur and magnesium on the growth and yield of potato. Pak. J. Biol. Sci. 2001; 4(9): 1090-1093. http://dx.doi. org/10.3923/pjbs.2001.1090.1093.

22. Van Delden A., Pecio A., Haverkort A.J. Temperature response of early foliar expansion of potato and wheat. Ann. Bot. 2000; 86: 355-369. http://dx.doi. org/10.1006/anbo.2000.1195.

23. Firman D.M., Allen E.J. Relationship between light interception, ground cover and leaf area index in potatoes. J. Agric. Sci. (Cambridge). 1989;113(3):355-359. http:// dx.doi.org/10.1017/S0021859600070040.

24. Rykaczewska K. Porównawcza analiza rozwoju, plonowania i wydajności fotosyntetycznej roślin dwóch bardzo wczesnych odmian ziemniaka: Ruta i Karatop. Cz. I. Analiza klasyczna i wskaźnikowa. / Comparative analysis of plant development, yielding and photosynthetic productivity of two very early potato cultivars: Ruta and Karatop. Part I. Classic and index analysis. Zesz. Probl. Post. Nauk Rol. 2004; 500: 167-179. (in Polish)
25. de la Casa A., Ovando G., Bressanini L., Martinez J., Rodriguez A. Eficiencia en el uso de la radiación en papa estimada a partir de la cobertura del follaje. /Radiation use efficiency in potato crop estimated from the foliage coverage. Agriscientia, 2011; 28(1): 21-30. (in Spanish)

26. Jabłoński K. Wpływ nawożenia wieloskładnikowymi nawozami nowej generacji na plon i jakość ziemniaka. / The effect of fertilization with new generation compound fertilizers on potato yield and quality. Zesz. Probl. Post. Nauk Rol. 2006; 511: 309-315. (in Polish)

27. Britto D.T., Kronzucker H.J. $\mathrm{NH}_{4}{ }^{+}$toxicity in higher plants: a critical review. J. Plant Phys. 2002; 159(6): 567-584. http://dx.doi.org/10.1078/0176-1617-0774.

\section{Wpływ wieloskładnikowych nawozów kompleksowych na wzrost roślin i plon bulw bardzo wczesnych odmian ziemniaka}

\section{Streszczenie}

Celem badań było porównanie wpływu wieloskładnikowych nawozów kompleksowych (HydroComplex, Nitrophoska Blue Special i Viking 13 z grupy nitrofosek i Polimag S z grupy amofosek) i nawozów jednoskładnikowych na wzrost roślin i plon bulw bardzo wczesnych odmian ziemniaka ('Aster', 'Fresco', 'Gloria'). Doświadczenie polowe przeprowadzono na glebie płowej w środkowo-wschodniej Polsce w latach 2005-2007. Przeprowadzone badania wykazały większy korzystny wpływ nawozów HydroComplex i Nitrophoska Blue Special na wzrost bardzo wczesnych odmian ziemniaka niż Viking 13 i Polimag S. Zastosowanie HydroComplexu i Nitrophoski Blue Special powodowało większy przyrost masy części nadziemnych roślin i powierzchni asymilacyjnej liści w porównaniu z nawozami jednoskładnikowymi; wskaźnik pokrycia liściowego (LAI) był większy odpowiednio o 0,28 i 0,32. Przy stosowaniu pozostałych wieloskładnikowych nawozów kompleksowych różnice były mniejsze i nie zostały potwierdzone statystycznie. Wskaźnik wagowy liści (LWR), wskaźnik ulistnienia rośliny (LAR) i ciężar jednostki powierzchni liści (SLA) przy stosowaniu wieloskładnikowych nawozów kompleksowych były podobne jak przy stosowaniu nawozów jednoskładnikowych. Spośród wieloskładnikowych nawozów kompleksowych tylko Nitrophoska Blue Special powodowała istotny przyrost plonu bulw, średnio o 2,40 $\mathrm{t} \times \mathrm{ha}^{-1}$, $\mathrm{w}$ porównaniu $\mathrm{z}$ nawozami jednoskładnikowymi. Reakcja badanych odmian na stosowane nawozy była podobna. LAI odmiany 'Gloria' był większy niż odmian 'Aster' i 'Fresco', przy mniejszym LWR tej 
odmiany. LWR odmiany 'Fresco' był mniejszy niż odmian 'Aster' i 'Gloria', przy większym SLA tej odmia- ny. Plon bulw odmiany 'Aster' (24,04 t'ha-1) był większy średnio o $3 \mathrm{t}^{\prime} \mathrm{ha}^{-1}$ niż odmian 'Fresco' i 'Gloria'.

Handling Editor: Elżbieta Weryszko-Chmielewska

This is an Open Access digital version of the article distributed under the terms of the Creative Commons Attribution 3.0 License (creativecommons.org/licenses/by/3.0/), which permits redistribution, commercial and non-commercial, provided that the article is properly cited.

(C) The Author(s) 2013 Published by Polish Botanical Society 